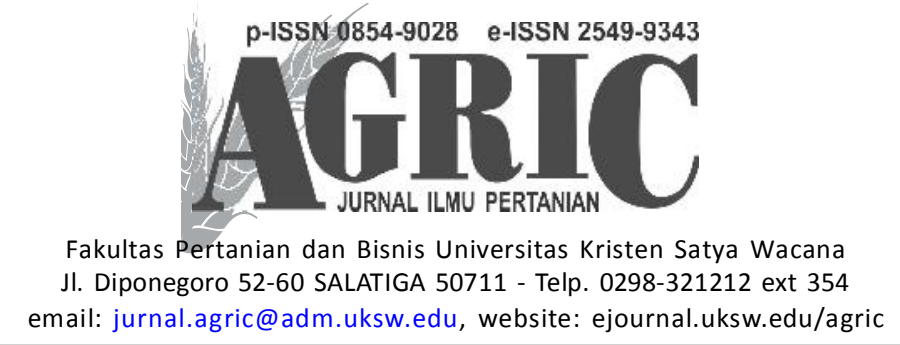

Terakreditasi Kementrian Riset, Teknologi dan Pendidikan Tinggi berdasarkan SK No 21/E/KPT/2018

\title{
EFFECT OF WATER STRESS ON OKRA YIELD AT VEGETATIVE STAGE
}

\author{
Farhan Ahmad Abdulrahman and Hawrez Ali Nadir \\ Sulaimani polytechnic university, Technical college of applied sciences, Plant production department, \\ Halabja, Kurdistan region-Iraq \\ E-mail: Hawrez.nadir@spu.edu.iq
}

Accepted: 4 Juny 2018,, approved 17 December 2018

\begin{abstract}
ABSTRAK
Penelitian ini dilaksanakan di Sekolah Tinggi Ilmu Pengetahuan Terapan, Universitas Politeknik Sulaimany, selama tahun 2017. Berbagai tingkat irigasi digunakan untuk produksi tanaman okra. Rancangan Acak Lengkap digunakan untuk mengatur tata letak percobaan, dengan tiga perlakuan tingkat irigasi dan empat ulangan. Hasil pengamatan yang dilakukan adalah bobot segar tanaman, bobot kering tanaman, faktor hasil dan respons tingkat irigasi yang berbeda. Hasil tertinggi ditunjukan dari perlakuan T1 (3.17 t.ha.-1) dan yang terendah ditunjukan dari T3 (2,988 t.ha.-1). Juga, berat segar maksimum dan kering bobot tanaman terlihat pada T1 $(61.40,11.218$ t.ha.-1), dan hasil terendah diperoleh pada perlakuan T3 $(57,00,8,783$ t.ha.-1). Efisiensi penggunaan air dan indeks panen tertinggi diperoleh dari T3 (1,615 kg.m-3, 0,095), dan terendah diperoleh dari perlakuan T1 (1,055 kg.m- 3, 0,094). Faktor respons tanaman dan hasil dalam penelitian ini menunjukkan bahwa tanaman okra memiliki respon stres air yang baik. Sebagai hasilnya, kami dapat merekomendasikan budidaya okra pada waktu itu tanpa irigasi di wilayah tersebut.
\end{abstract}

Kata kunci: Crop yield response factor, Harvest index, Okra, Water use efficiency, Vield.

\begin{abstract}
This study was conducted in Technical College of Applied Sciences, Sulaimany Polytechnic University, during 2017. Different levels of irrigation were used to production of okra plant. Complete Randomize Design used to layout of the experiment, with three level of irrigation in four replications. Yield, fresh weight of plant, dry weight of plant, yield response factor and different levels of irrigation were observed. The highest yield was given from treatment $T_{1}(3.17$ t.ha. $\left.{ }^{-1}\right)$ and the lowest was given from $T_{3}\left(2.988\right.$ t.ha. $\left.{ }^{-1}\right)$. Also, the maximum fresh weight and dry weight of plant were given from $T_{1}\left(61.40,11.218 \mathrm{t}^{-h} \mathrm{~h}^{-1}\right)$, and their minimum was given from treatment $T_{3}\left(57.00,8.783\right.$ t.ha. $\left.{ }^{-1}\right)$. The highest water use efficiency and harvest index were obtained from $T_{3}\left(1.615 \mathrm{~kg} . \mathrm{m}^{-3}, 0.095\right)$, and the lowest was given from treatment $T_{1}(1.055 \mathrm{~kg} . \mathrm{m}$ 3 , 0.094). The crop response factor and the results in this study showed that the okra plants have a good response of water stress. As a result, we can recommend cultivating the okra at that time without irrigation in that region.
\end{abstract}

Keyword: Crop yield response factor, Harvest index, Okra, Water use efficiency, Yield. 


\section{INTRODUCTION}

The okra plant, Abelmoschus esculentus (L.), Moench, is an annual vegetable crop; it is belonging to the family of (Malvaceea). It is more popular vegetable in the world and acceptable in the market (Farias et al. 2017). Also, okra pods contain carbohydrate, protein and vitamin (Farinde et al., 2007; Varmudy, 2011). Okra plant has the same comparable soybean, containing essential and nonessential amino acid (Farinde et al, 2007). However, okra pods has great important role in human nutrition (El-Kader et al., 2010; Varmudy, 2011).

Okra plant is cultivated throughout tropical and subtropical region (Akinyele \& Osekita, 2006). To product the vegetable in the word, it needs an amount of water. Consequently, demand for water usage in the word has increased in both agricultural and particular government sectors at high rates (Singh \& Rajput, 2007).

Both drip and surface irrigation are most popular applied in agricultural sectors. Drip irrigation has some advantages such as decreasing evaporation, more efficiency of water use, reducing water waste and easily managing the water to applied nutrition and some pesticide and fungicide (Singh \& Rajput, 2007; Sengkhamparn, 2009). However, drip irrigation enhances the yield and quality of the crops (Camp, 1998; Sengkhamparn, 2009).

In order to reduce waste of water in agriculture and to use fewer water in irrigation, it is necessary to manage the implementation irrigation system (Agodzo, et al., 1997). However, the efficiency of water to irrigation crop affects productive characteristic (Farinde et al., 2007). Moreover, water stress on the plants directly impact the reduced fruit dry matter and yield of the plant (Bhatt\& Srinivasarao, 2005; Sankar et al., 2008; Bahadur et al., 2009).

Recently, in Kurdistan Region-Iraq, water utilization in agricultural sectors and decreasing water in that country have spread; hence, in the future, water use has to be decreased in agricultural particularly in municipal, sector by applying the right way to irrigation the plant. The aim of the study is to test the effects of water stress on the yield and vegetative stage of okra.

\section{Material and Methods}

Field experiment for the study was conducted in Technical College of Applied Sciences, Halabja, Sulaimani Polytechnic University, during spring season of (2017), and location of the experiment area on (35'12'47.4"N latitude 45 57'34.9"E longitude), and the altitude $(690 \mathrm{~m})$ above sea level. The local cultivar of okra was used to observation the Yield ton/ hectare, amount of water use, weight of plant ton /hectare and dry weight ton/hectare. The average rainfall in the area was between $(650-700 \mathrm{~mm})$ in 2017 , the relative humidity $(55 \pm 30 \%)$ and air temperature $(18 \pm 10 \mathrm{C} 0)$. Also, surface irrigation systems are used to irrigate the Okra in that region and applied two times a week.

In this study, the experiment compose of cultivates okra plant, irrigation unit and germinate seed. Then, it is divided in to three treatments: first, normally, irrigation weekly depends on soil moisture; second, irrigation the plant one time after germination until flowering; and third, treatment okra plant does not have irrigation from germination until flowering Table 2. Complete randomize design is used to layout 
for the experiment. The experiment area ploughed twice and is divided in to 12 equal plots with 3 treatments and 4 replications, and the dimensions of plot $(6 \mathrm{~m})$ length and $(3 \mathrm{~m})$ width and the line width $(0.75 \mathrm{~cm})$ spacing, the spacing between the plants are $(25 \times 25 \mathrm{~cm})$.

Okra seeds were sown on 15of April 2017. In this experiment, $1.5 \mathrm{~kg} / \mathrm{sub}$ plot of Diamonium Phosphate was applied by broadcasting at time of crop sowing. Gravimetric method was used to determine the moisture content of the soil. To determine the soil chemical, physical characteristic is digging the soil $(60 \mathrm{~cm})$ depth Table 1.

The irrigation process for first treatment was applied when $50 \%$ of the available water was depleted, and then $50 \%$ of water was added to reach $100 \%$ of the available water. Drip irrigation is used to irrigation of okra. Depth of irrigation water was calculated by following equation Eq. (1):

$\mathrm{D}=0.5 \mathrm{Aw} * \mathrm{Rz}$
Where:

D: Applied of water (mm)

$A w$ : Available water (Difference between field capacity and wilting point.

$0.5 \mathrm{Aw}$ : Volumetric water content when $50 \%$ of available water was depleted $\left(\mathrm{m}^{3} / \mathrm{m}^{3}\right)$

Rz: root zone depth according plant growth stage $(10: 20: 30 \mathrm{~cm})$ for each month (April, May and Jun) respectively.

Use the following equation to find the field water use efficiency, and harvesting index was calculated by the equation given by Hunt (1978) Eq. (2).

F.W.U.E $=\frac{\text { Yield }\lceil\mathrm{Kg}}{\text { amount of water applied }\left[\mathrm{m}^{-3} \llbracket\right.}$

The crop yield response factor (Ky) was estimated by using the equation reduction in relative yield Stewant's model Eq. (3), as given below:

[1-ya/ym= ky $(1-E t a / E t c)]$

The estimate value of (ky) depends on the maximum yield from full irrigation treatment and

Table 1 Chemical and physical properties of the soil

\begin{tabular}{lclc}
\hline Chemical properties & Value/Unit & Physical properties & Value/Unit \\
\hline Organic mater & $20 \mathrm{~g} \mathrm{~kg}^{-1}$ & Sand & $133.6 \mathrm{~g} \mathrm{~kg}^{-1}$ \\
$\mathrm{PH}$ & 7.57 & Silt & $244.3 \mathrm{~g} \mathrm{~kg}^{-1}$ \\
EC & $1.4 \mathrm{dS} \mathrm{m}^{-1}$ & Clay & $622.1 \mathrm{~g} \mathrm{~kg}^{-1}$ \\
PH water & 7.7 & Soil texture & Clay \\
EC water & $1.05 \mathrm{dS} \mathrm{m}^{-1}$ & Bulk density & $1200 \mathrm{Kg} \mathrm{m}^{-3}$ \\
Total Nitrogen & $20 \mathrm{mg} \mathrm{kg}^{-1}$ & Field capacity, ( 33 & $320 \mathrm{~g} \mathrm{~kg}^{-1}$ \\
& & $\mathrm{kPa})$ & \\
Phosphors (soluble) & $19 \mathrm{mg} \mathrm{kg}^{-1}$ & Wilting point, $(1500$ & $188 \mathrm{~g} \mathrm{~kg}^{-1}$ \\
& & $\mathrm{kPa})$ & \\
Potassium (soluble) & $13.7 \mathrm{Meq} \mathrm{kg}^{-1}$ & & \\
alcium (soluble) & $7.5 \mathrm{Meq} \mathrm{kg}^{-1}$ & & \\
Magnesium (soluble) & $2.8 \mathrm{Meq} \mathrm{kg}^{-1}$ & & \\
Sodium (soluble) & $6.3 \mathrm{Meq} \mathrm{kg}^{-1}$ & & \\
\hline
\end{tabular}


yield of treatment that exposed to stress. The amount of water used in this study illustrated in Table 2 . The data were analyzed by one-way ANOVA using (XLSTAT-pro version 7.5.2) program with comparison L.S.D at $\mathrm{P}<0.05$.

Table 2 Amount of water was used in this study

\begin{tabular}{cccc}
\hline Plant age/ & \multicolumn{3}{c}{ Depth of water applied } \\
\cline { 2 - 4 } week & $\mathbf{T}_{\mathbf{1}}$ & $\mathbf{T}_{\mathbf{2}}$ & $\mathbf{T}_{\mathbf{3}}$ \\
\hline 1 & 1.44 & 1.44 & 1.44 \\
2 & 1.44 & - & - \\
3 & 1.44 & - & - \\
4 & 2.88 & 2.88 & - \\
5 & 2.88 & - & - \\
6 & 2.88 & - & - \\
7 & 4.32 & 4.32 & 4.32 \\
8 & 4.32 & 4.32 & 4.32 \\
9 & 4.32 & 4.32 & 4.32 \\
10 & 4.32 & 4.32 & 4.32 \\
Total & $30.24 \mathrm{~cm}$ & $21.60 \mathrm{~cm}$ & $18.72 \mathrm{~cm}$ \\
\hline
\end{tabular}

\section{Results and Discussion}

Effect of water stress on the yield was shown in figure 1 . The results showed a significant vary between the different levels of irrigation at $\mathrm{P}<0.05$. The maximum yield was obtained from the treatment one (3.17 t.ha. ${ }^{-1}$ ), and the minimum was given from treatment three (2.988 t.ha. ${ }^{-1}$ ). Those results agree with those Singh \& Rajput, (2007), who worked on okra using subsurface of drip irrigation and (Bhatt\& Srinivasarao, 2005; Bahadur, 2009; Akande, et al., 2010). Observing the results of the study, the yield from treatment three compared with other treatments economically is not a significant different, but statically different, because the amount of water use is much less than the other treatments. Also, Sankar et al., 2008 stated that the water stress affects to the yield and Martin, 2000 stated that too little water with too much water both effect to yield reduction. Otherwise, the results disagree with (Dilruba, et al., 2009), who worked on okra using the growth hormone.

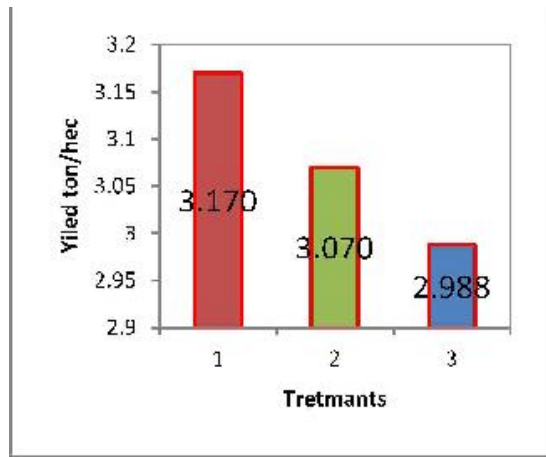

Figure 1 Effect of different levels of irrigation on the yield

The weight of vegetative part of plant and the dry weight of vegetative part of plant were illustrated in Table 3. The highest weight of fresh vegetative part for three treatments and four replications was given from $\mathrm{T}_{1}\left(61.40\right.$ t.ha. $\left.^{-1}\right)$, and the lowest was obtained from $\mathrm{T}_{3}(57.00$ t.ha. ${ }^{-1}$ ). The result showed a significant different between treatment at $\mathrm{p}<0.05$. In case the amount of water use to irrigate the okra plant affect to the fresh weight of the okra plant. Also, the results agree with (Zodape, et al., 2008) worked on okra plant use liquid fertilizer to increase yield and quality, and showed in that result the amount of use water with fertilize directly affect to the growth and vegetative part with yield. El-Kader et al., 2010) who recorded the same result using the water by drip irrigation to increase the yield and quality of okra as well as. However, the highest weight of dry vegetative part was given in $\mathrm{T}_{1}(11.218$ t.ha. $\left.{ }^{-1}\right)$ and the lowest was given in $\mathrm{T}_{3}(8.783$ t.ha. ${ }^{-1}$ ). The results of dry weight of okra plant under water stress agree with (Zodape, et al., 2008), because the water in to the plant have a majority role to growth. So that, the okra plant like other plants need to the water to growth but in that study showed the okra plant not irrigated form that time. 
Table 3 Effect of different levels of irrigation on the weight of vegetative part of the Okra plant

\begin{tabular}{ccc}
\hline Treatments & $\begin{array}{c}\text { Weight of } \\
\text { fresh } \\
\text { vegetative } \\
\text { part t.ha. }^{-1}\end{array}$ & $\begin{array}{c}\text { Weight of dry } \\
\text { vegetative part }\end{array}$ \\
t.ha. $^{-1}$
\end{tabular}

L.S.D. comparison at $\mathrm{p}<0.05$ the same letter show no significant otherwise to different

In this study, the field water use efficiency and harvest index clarified the results in Table 4. Water use efficiency refers the ratio between amount of water retained in the root zoon and the amount of water applied (Martin, 2000). The comparison between treatments to field water use efficiency showed a significant different at $\mathrm{p}<0.05$. The highest water use efficiency and harvest index was given from treatment $\mathrm{T}_{3}\left(1.615 \mathrm{~kg} \cdot \mathrm{m}^{-3}, 0.095\right)$. Moreover, not irrigation for a long time from flowering in okra plant effect to reduce the loss water, because the stomata closure and decreased $\mathrm{CO}_{2}$ fixation. This illustrated the photosynthesis in the plant increased at the cost of water loss affected to use water efficiency. The results of water use efficiency agree with Bahadur, (2009). The results of harvest index showed no significant different between treatments.

The crop yield response factor of okra is showed in Table 5. The rustles showed that the ratio of response factor of water in okra plant is near to zero. Thus, the okra plants resist to water stress, because okra plant a deep taproot, semi woody stem and leaves are lobed with hairy and when the plants they suffer water deficiency this stress tend to close their stomata and thus reduce the photosynthetic rate (Farias et al. 2017). Also, that results agreed with Sankar $e t$ al., (2008).

Table 4 Illustrated the Field water use efficiency and harvest index

\begin{tabular}{ccc}
\hline Treatments & $\begin{array}{c}\text { F.W.U.E. } \\
\text { (kg.m }{ }^{-3}\end{array}$ & Harvest index \\
\hline $\mathrm{T}_{1}$ & $1.055 \mathrm{a}$ & $0.094 \mathrm{a}$ \\
$\mathrm{T}_{2}$ & $1.435 \mathrm{~b}$ & $0.095 \mathrm{a}$ \\
$\mathrm{T}_{3}$ & $1.615 \mathrm{c}$ & $0.095 \mathrm{a}$ \\
\hline
\end{tabular}

F.W.U.E.: field water use efficiency, L.S.D. comparison at $\mathrm{p}<0.05$ the same letter show no significant otherwise to different letter

\section{CONCLUSION}

In this study, the results of the okra yield showed no economical different. Hence, an amount of water can be saved without effect of the reducing okra yield. Thus, it has been recommended that the okra plant should not be irrigated until flowering in that region because of okra plant resistance to water stress. Also, it has been recommended that other researchers should work on different crops in that region in the future.

Table 5 Show the yield of okra plant response factors of water

\begin{tabular}{cccccc}
\hline Treatments & $\begin{array}{c}\text { Yield kg/ha. } \\
\text { Mena }\end{array}$ & $\begin{array}{c}\text { W. applied } \\
\mathbf{m}^{\mathbf{3}} / \mathbf{h a} \text {. Mena }\end{array}$ & $\mathbf{1 - Y a / Y m}$ & $\mathbf{1 - W a} / \mathbf{W m}$ & $\mathbf{K y}$ \\
\hline $\mathbf{T}_{\mathbf{1}}$ & 3205 & 3024 & - & - & - \\
$\mathbf{T}_{\mathbf{2}}$ & 3105 & 2160 & 0.03 & 0.28 & 0.10 \\
$\mathbf{T}_{\mathbf{3}}$ & 3016 & 1872 & 0.06 & 0.38 & 0.15 \\
\hline
\end{tabular}




\section{REFERENCES}

Agodzo, S. K., Nishio, T., \& Yamamoto, T. 1997. Trickle irrigation of okra based on small pan evaporation schedule under glasshouse condition. Rural and EnvironmentEngineering, 1997(33), 1936.

Akande, M. O., Oluwatoyinbo, F. I., Makinde, E. A., Adepoju, A. S., \& Adepoju, I. S. 2010. Response of okra to organic and inorganic fertilization. Nature and Science, 8(11), 261-266.

Akinyele, B. O., \& Osekita, O. S. 2006. Correlation and path coefficient analyses of seed yield attributes in okra (Abelmoschus esculentus (L.) Moench). African Journal of Biotechnology, 5(14), pp. 1330-1336.

Araújo, M. I. D. F., \& de Jesus, T. S. 2017. Efficiency in water use and yield of okra (Abelmoschus esculentus) in response to different levels of irrigation. Revista Brasileira de Agricultura Irrigada v, 11(5), 17321737.

Bahadur, A., Singh, K. P., Rai, A., Verma, A., \& Rai, M. 2009. Physiological and yield response of okra (Abelmoschus esculentus) to irrigation scheduling and organic mulching. Indian Journal of Agricultural Sciences, 79(10), 813-15.

Bhatt, R. M., \& Rao, N. S. 2005. Influence of pod load on response of okra to water stress. Indian journal of plant physiology, 10(1), 54.

Camp, C.R. 1998. (Subsurface drip irrigation), A review. Trans ASAE, 41, 1353-1367.

Dilruba, S., Hasanuzzaman, M., Karim, R., \& Nahar, K. 2009. Yield response of okra to different sowing time and application of growth hormones. J. Hortic. Sci. Ornamental Plants, 1, 10-14.

El-Kader, A., Shaaban, S. M., \& El-Fattah, M. 2010. Effect of irrigation levels and organic compost on okra plants (Abelmoschus esculentus L.) grown in sandy calcareous soil. Agric Biol JN Am, 1(3), 225-231.

Farinde, A. J., Owolarafe, O. K., \& Ogungbemi, O. I. 2007. An overview of production, processing, marketing and utilisation of okra in egbedore local government area of Osun State, Nigeria. Agricultural Engineering International: CIGR Journal.

Hunt, R. 1978. Growth analysis of individual plants. Plant Growth Analysis.

Sankar, B., Jaleel, C. A., Manivannan, P., Kishorekumar, A., Somasundaram, R., \& Panneerselvam, R. 2008. Relative efficacy of water use in five varieties of Abelmoschus esculentus (L.) Moench. Under water-limited conditions. Colloids and Surfaces B: Biointerfaces, 62(1), 125-129.

Sengkhamparn, N. 2009. Chemical, physical and biological features of Okra pectin.

Singh, D. K., \& Rajput, T. B. S. 2007. Response of lateral placement depths of subsurface drip irrigation on okra (Abelmoschus esculentus). International Journal of Plant Production, 1, 1,73-84.

Varmudy, V. 2011. Need to boost okra exports. Facts For You, 31(5), 21-23.

Zodape, S. T., Kawarkhe, V. J., Patolia, J. S., \& Warade, A. D. 2008. Effect of liquid seaweed fertilizer on yield and quality of okra (Abelmoschus esculentus L.). 